Human Rights Law Review 8:1 C) The Author [2008]. Published by Oxford University Press. All rights reserved. For Permissions, please email: journals.permissions@oxfordjournals.org doi:10.1093/hrlr/ngm045 Advance Access published on 1 February 2008

\title{
Putting Flesh on the Skeleton: South African Judicial Enforcement of the Right to Adequate Housing of Those Subject to Evictions
}

\author{
Lilian Chenwi*
}

\begin{abstract}
Access to adequate housing is one of the greatest challenges facing the South African government today. The country's housing situation is characterised by a severe housing shortage, a huge backlog in the provision of housing, provision of inadequate housing and severe overcrowding in existing dwellings. In addition, evictions that at times result in homelessness are a daily occurrence. The government has put in place a number of legislative and other measures aimed at realising the right to adequate housing. However, the difficulty that remains is translating these laws and policies into reality, resulting in safe, secure and affordable living conditions for the poor and vulnerable. This article examines how South African courts have sought to enforce the right to adequate housing of those faced with evictions through interpreting the constitutional provision on this right and the corresponding state duty, while at the same time, protecting the rights of landowners.
\end{abstract}

\section{Introduction}

The right to adequate housing is of central importance for the enjoyment of all socio-economic rights, as well as other human rights. It includes, amongst others, the right to protection from arbitrary or unlawful interference with 
privacy, family or home and to legal security of tenure. ${ }^{1}$ It therefore mirrors a prohibition of forced or arbitrary eviction. ${ }^{2}$ Every state has a legal obligation to respect, protect, promote and fulfil the right to adequate housing, and by inference not to sponsor, tolerate or carry out forced evictions. ${ }^{3}$ The obligations of states in this regard arise from several international instruments protecting the right to adequate housing and other related human rights. ${ }^{4}$ States are required to adopt appropriate legislative and policy measures to ensure the protection of individuals, groups and communities against evictions that are not in conformity with existing human rights standards. ${ }^{5}$ In other words, states must ensure that the right to adequate housing and secure tenure and the protection against forced evictions are guaranteed without discrimination of any kind.

Several international bodies have developed consistent standards unequivocally stating that forced evictions constitute grave violations of human rights, especially the right to adequate housing. For instance, the United Nations (UN) Committee on Economic, Social and Cultural Rights (CESCR), in expanding on the meaning of the right to adequate housing under Article 11 of the ICESCR, placed considerable emphasis on forced evictions. The CESCR noted that forced evictions are prima facie incompatible with the requirements of the Covenant'. Also, the UN Commission on Human Rights (replaced by the Human Rights Council) held that the practice of forced eviction constitutes a gross violation of human rights especially the right to adequate housing. ${ }^{7}$

1 See generally, Committee on Economic, Social and Cultural Rights (CESCR) General Comment No. 4, The right to adequate housing, 13 December 1991, E/1992/23.

2 155/96, Social and Economic Rights Action Centre and the Centre for Economic and Social Rights $v$ Nigeria 15th Annual Activity Report of the ACHPR (2002); 10 IHRR 282 (2003) (SERAC) at para. 61.

3 UN Fact Sheet No. 25, Forced Evictions and Human Rights, 23 June 1993, A/CONF.157/24 at part 1, chap. III, available at http://www.ohchr.org/Documents/Publications/FactSheet25en.pdf [last accessed 28 January 2008]. See also UN Fact Sheet No. 21, The Human Right to Adequate Housing, available at http://www.ohchr.org/Documents/Publications/FactSheet2len.pdf [last accessed 28 January 2008].

4 Article 25, Universal Declaration on Human Rights 1948, GA Res.217 A (III), 10 December 1948, A/810 (UDHR); Article 11(1), International Covenant on Economic, Social and Cultural Rights 1966, 993 UNTS 3 (ICESCR); Article 14(2)(h) Convention on the Elimination of all Forms of Discrimination against Women 1979, 1249 UNTS 13 (CEDAW); Article 5(e)(iii), Convention on the Elimination of all Forms of Racial Discrimination 1965, 660 UNTS 195 (CERD); and Article 27(3), Convention on the Rights of the Child 1989, 1577 UNTS 3 (CRC). Although the right to housing is not explicitly provided for under the African Charter on Human and Peoples' Rights 1981, 27 June 1981, OAU CAB/LEG/67/3rev.5; 21 ILM 58 (1982) (African Charter), the African Commission on Human and Peoples' Rights (African Commission), the supervisory body of the African Charter, has found the right to be implicit in Articles 14 (right to property), 16 (right to the best attainable state of physical and mental health) and 18(1) (protection of the family), read together: Social and Economic Rights Action Centre and the Centre for Economic and Social Rights $v$ Nigeria, supra n. 2 at para. 60.

5 See generally, CESCR General Comment No. 3, The nature of states parties obligations, 14 December 1990, E/1991/23.

6 General Comment No. 4, supra n. 1 at para. 18.

7 Res. 2004/28, Prohibition of Forced Evictions, 16 April 2004, E/2004/23-E/CN.4/2004/127, chap. X at para. 1. See also Res. 1993/77, Forced Evictions, 10 March 1993, at para. 1. 
In addition, the African Commission on Human and Peoples' Rights (African Commission) has observed that forced evictions have a drastic impact on peoples' socio-economic, physical and psychological well being, increasing existing levels of homelessness. ${ }^{8}$ In the words of the African Commission: "Wherever and whenever they occur, forced evictions are extremely traumatic. They cause physical, psychological and emotional distress; they entail losses of means of economic sustenance and increase impoverishment. They can also cause physical injury and in some cases sporadic deaths . . Evictions break up families and increase existing levels of homelessness. ${ }^{9}$

Despite these adverse effects, globally, millions of people are forcibly evicted on a yearly basis, leaving them homeless and, in the process, entrenching patterns of poverty, discrimination and sexual exclusion. ${ }^{10}$ These are often large-scale evictions - entire communities of tens or even hundreds of thousands of people are removed. They are invariably evicted against their will, in most cases without any compensation or alternative housing. ${ }^{11}$ In Africa, forced evictions, with or without judicial backing, have increased at an alarming rate. Between 2003 and 2006, an estimated 2,004,171 people were evicted. ${ }^{12}$ In most instances, those evicted are left homeless, losing their possessions without compensation or are forcibly displaced far from sources of employment, livelihood or education, all in violation of international human rights law. ${ }^{13}$

South Africa, though hailed for its progressive housing laws, jurisprudence, policies and programmes, is not free of this crisis. The practice of evictions is a regular occurrence in the country, in both urban and rural areas. Between 1995 and 2005, 826,679 people were reportedly evicted. ${ }^{14}$ As seen

Similarly, the UN Sub-Commission on Prevention of Discrimination and Protection of Minorities has stated, on several occasions, that the practice of forced eviction constitutes a gross violation of a broad range of human rights, particularly the right to adequate housing: see Res. 1993/36, Promoting the realization of the right to adequate housing, 25 August 1993; Res. 1993/41, Forced evictions, 26 August 1993; and Res. 1994/39, Forced evictions, 26 August 1994, available at: http://ww2.unhabitat.org/programmes/housingrights/unhrpresolutions. asp [last accessed 22 November 2007].

8 South Africa ratified the African Charter on 9 July 1996.

9 Social and Economic Rights Action Centre and the Centre for Economic and Social Rights v Nigeria, supra n. 2 at para. 63.

10 Du Plessis, 'Forced Evictions, Development and the Need for Community-Based, Locally Appropriate Alternative: Lessons and Challenges from South Africa, Ghana and Thailand', in Huchzermeyer and Karam (eds), Informal Settlements: A Perpetual Challenge? (Johannesburg: UCT Press, 2006) 180 at 180.

11 Du Plessis, 'Forced Evictions: A Global Perspective', (2006) 7(3) ESR Review 3 at 3.

12 See generally, Centre on Housing Rights and Evictions (COHRE), 'Forced Evictions-Violations of Human Rights', (2006) 10 Global Survey 11, available at: http://www.cohre.org/view. page.php? page.id=119 [last accessed 22 November 2007]. See also COHRE, 'Focus on Africa', August 2005, 1(3) Evictions Monitor, available at: http://www.cohre.org/view_page. php?pageid=176 [last accessed 22 November 2007].

13 Amnesty International, Public Statement, Africa: Forced Evictions are a Human Rights Scandal, 3 October 2005, AI Index: AFR 01/003/2005, available at: http://web.amnesty.org/library/ Index/ENGAFR010032005 [last accessed 22 November 2007].

14 Du Plessis, supra n. 11 at 6. See also, Wegerif, Russell and Grundling, Still Searching for Security. The Reality of Farm Dweller Evictions in South Africa (Polkwane North: Nkuzi 
below, legislation and policies aimed at providing procedural and substantive protection to people faced with evictions have been enacted or adopted. However, the complexity of legislation on eviction and its allowance of urgent eviction applications, more often than not result in evictions taking place without adherence to the procedural and substantive requirements. The poorest and most vulnerable members of the society are evicted without being given an opportunity to present their case in court (or oppose the eviction) or adequate notice of when the eviction order will be carried out; with some of the eviction orders executed at night. ${ }^{15}$ Others have been evicted without the provision of alternative accommodation. ${ }^{16}$ Hence, evictions often occur in a manner that is incompatible with the fundamental values of respect for human rights; resulting in the violation of, inter alia, the rights to dignity, health, security of the person, livelihood and adequate housing. The courts have, accordingly, sought to enforce the right to adequate housing of those faced with evictions; while at the same time, protecting the rights of landowners.

The aim of this article is to show how South African courts have strived in ensuring greater protection for those faced with evictions, through interpreting the constitutional rights to adequate housing and to protection against arbitrary evictions, and the corresponding state duty. Though reference is also made to the decisions of other courts, the focus is mainly on the jurisprudence of the Constitutional Court, which is the highest court in all constitutional matters. The article also examines, albeit briefly, how the courts, in the process of protecting those faced with evictions, have given consideration to the various interests involved, in particular, the rights of landowners. These issues are considered against the international, historical and legal context, as the Constitutional Court has, on numerous instances, emphasised that the rights in the Constitution of the Republic of South Africa 1996 (the Constitution) cannot be interpreted in the abstract but in the light of their context. ${ }^{17}$

Development Association, and Johannesburg: Social Surveys, December 2005). With regard to farm dwellers, between 1994 and 2004, 1,679,417 farm dwellers were reportedly evicted: see Wegerif, 'Farm Evictions: A Failure of Rights' (2006) 7 ESR Review 8 at 9.

15 UN Press Release, Statement of the UN Special Rapporteur, Miloon Kothari, on Adequate Housing in light of his Mission to South Africa (12 April to 24 April 2007), 7 May 2007.

16 South African Human Rights Commission (SAHRC), 6th Economic and Social Rights Report: 2003-2006 (Johannesburg: South African Human Rights Commission, 2006) at 6.

17 For instance, in Government of the Republic of South Africa and Others v Grootboom 2001 (1) SA 46 (CC) at para. 25, the Court stated that rights need to be interpreted and understood in their social and historical context. The Grootboom case concerned a number of people, including children, who had moved from an informal settlement onto private land earmarked for low-cost housing owing to the 'appalling conditions' in which they were living. They were evicted from the private land, which they were unlawfully occupying. Following the eviction, they camped on a sports field in the area and approached the courts to enforce their right of access to adequate housing. They alleged that the state's housing programme violated their right to have access to adequate housing guaranteed under Section 26, Constitution. The respondents in this case also sought to enforce their children's right to shelter under Section 


\section{International Standards on Evictions}

South Africa has a range of housing (and housing-related) obligations in terms of international human rights instruments that guarantee the right to adequate housing. The obligations include recognising the right to adequate housing, including the right to be protected from arbitrary evictions, through the ratification of international treaties, as well as not only including housing rights and the prohibition of arbitrary evictions in the Constitution and other housing legislation but also enforcing them.

International standards on evictions are relevant because South African courts cannot completely disregard international law provisions and subsequent interpretations. Section 39(1) of the Constitution requires the courts to consider international law when interpreting the rights in the Constitution. Also, Section 233 of the Constitution requires every court, when interpreting any legislation, to give preference to any reasonable interpretation of the legislation that is consistent with international law. As observed by the Constitutional Court, international law and standards in non-binding international instruments provides a framework within which the rights in the Constitution can be evaluated and understood. ${ }^{18}$ Accordingly, the courts have referred to international law when construing the right to adequate housing in eviction cases, though the weight attached to any rule of international law varies from case to case. ${ }^{19}$ If the relevant principle or rule of international law binds South Africa, it may be directly applicable. But where it is not directly binding, though it could be relied on by the courts, its impact will be limited where significant differences exist in the wordings of the provisions of the international instrument and the provisions of the Constitution, as is the case with the ICESCR and the Constitution as regards the right to adequate housing. ${ }^{20}$

The right to adequate housing, as guaranteed in the ICESCR, has been elaborated upon by the CESCR in General Comment No. $4 .^{21}$ The relevant general comments on the interpretation and application of the ICESCR are

28(1)(c), Constitution. Basically, when ruling in their favour, the Court held that the obligation imposed on the state is to put in place a reasonable programme, subject to available resources, to realise the right of access to adequate housing. Regarding the children, it held that the primary obligation to provide for children's needs lies with their parents and on the state only when such children have been removed from the care of parents.

18 See S v Makwanyaye and Another 1995 (3) SA 391 (CC) at para. 35, which concerned the constitutionality of the death penalty.

19 Government of the Republic of South Africa and Others v Grootboom, supra n. 17 at para. 26.

20 The ICESCR provides for 'a right to adequate housing' while the Constitution, as interpreted, provides for 'the right of access to adequate housing'.

21 Supra n. 1. Article 11(1), ICESCR reads:

The States Parties to the present Covenant recognize the right of everyone to an adequate standard of living for himself and his family, including adequate food, clothing and housing, and to the continuous improvement of living conditions. The States Parties will take appropriate steps to ensure the realization of this right, recognizing to this effect the essential importance of international co-operation based on free consent. 
important and useful for the courts in interpreting the right to adequate housing in the South African context. Actually, the Constitutional Court has relied directly on, for example, General Comment No. 3 of the CESCR. As seen subsequently, it has endorsed a passage from it on the meaning of 'progressive realisation' in the context of the Constitution. ${ }^{22}$ In General Comment No. 4, the CESCR identified a number of factors to be taken into account in determining whether particular forms of shelter can be considered to constitute 'adequate housing' for the purposes of the ICESCR. These include: legal security of tenure; availability of services materials, facilities and infrastructure; affordability; habitability; accessibility; location; and cultural adequacy. ${ }^{23}$ The CESCR added that 'all persons should possess a degree of security of tenure which guarantees legal protection against forced eviction, harassment and other threats. ${ }^{24}$

The CESCR has been more specific in relation to due process in the context of evictions. It has identified procedural requirements to be applied in the case of an eviction, which have been useful to South African courts when interpreting the right to protection against arbitrary evictions. These include:

(a) an opportunity for genuine consultation with those affected;

(b) adequate and reasonable notice for all affected persons prior to the scheduled date of eviction; (c) information on the proposed evictions, and, where applicable, on the alternative purpose for which the land or housing is to be used, to be made available in reasonable time to all those affected; (d) especially where groups of people are involved, government officials or their representatives to be present during an eviction; (e) all persons carrying out the eviction to be properly identified; (f) evictions not to take place in particularly bad weather or at night unless the affected persons consent otherwise; (g) provision of legal remedies; and (h) provision, where possible, of legal aid to persons who are in need of it to seek redress from the courts. ${ }^{25}$

The CESCR is also of the view that evictions should not result in individuals being rendered homeless or vulnerable to the violation of other human rights. Prior to an eviction and particularly those involving large groups, states have an obligation to explore all feasible alternatives in consultation with the affected persons, with a view to avoiding, or at least minimising, the need to use force. $^{26}$ The state also has an obligation to ensure that adequate alternative

Government of the Republic of South Africa and Others v Grootboom supra n. 17 at para. 45. General Comment No. 4, supra n. 1 at para. 8.

Ibid. at para. $8 \mathrm{a}$.

CESCR General Comment No. 7, Right to adequate housing: Forced evictions, 1997, E/1998/22, Annex IV at para. 15.

Ibid. at para. 13. 
housing, resettlement or access to productive land, as the case may be, is available to affected persons who are unable to provide for themselves. ${ }^{27}$

The UN Commission on Human Rights has urged governments to immediately undertake measures at all levels aimed at eliminating the practice of forced eviction by, amongst others, repealing existing plans involving forced evictions as well as any legislation allowing for forced evictions, and by adopting and implementing legislation ensuring the right to security of tenure for all residents. ${ }^{28}$ Governments are also required to adopt all necessary measures giving full protection against forced eviction, based upon effective participation, consultation and negotiation with affected persons or groups. ${ }^{29}$ They are further required to provide appropriate and sufficient alternative accommodation or land to persons and communities that have been forcibly evicted, following mutually satisfactory negotiations with the affected persons or groups and consistent with their wishes, rights and needs. ${ }^{30}$ It added that governments must ensure that 'any eviction that is otherwise deemed lawful is carried out in a manner that does not violate any of the human rights of those evicted. ${ }^{31}$

Furthermore, guidelines have been developed in relation to evictions linked to development. In 1997, the guidelines on development-based displacement were adopted. ${ }^{32}$ The guidelines place obligations on states, inter alia, to secure by all appropriate means, including the provision of security of tenure, the maximum degree of effective protection against the practice of forced evictions for all persons; to prevent homelessness; and to explore all possible alternatives to any act involving forced eviction. The need to further strengthen and put forward in more operational terms the above guidelines has resulted in the development of the Basic Principles and Guidelines on Development-Based Evictions and Displacement (Basic Principles and Guidelines), aimed at assisting states and the international community in significantly reducing the practice of forced evictions. ${ }^{33}$ The Basic Principles and Guidelines enumerate, inter alia, detailed steps to be taken by states prior to, during, and after evictions. ${ }^{34}$ The procedural requirements prior to and during evictions are similar to those stated by the CESCR in General

27 Ibid. at para. 16.

28 Supra n. 7 at para. 2. The UN Sub Commission on the Promotion and Protection of Human Rights has also urged governments to undertake immediate measures, at all levels, aimed at eliminating the practice of forced evictions: see Res. 1992/14, 27 August 1992.

29 Ibid. at para. 3.

30 Ibid. at para. 4.

31 Ibid. at para. 5.

32 Expert Seminar on the Practice of Forced Evictions, Comprehensive Human Rights Guidelines on Development-Based Displacement, 11-13 June 1997, E/CN.4/Sub.2/1997/7.

33 See Report of the UN Special Rapporteur on adequate housing as a component of the right to an adequate standard of living, Miloon Kothari, 5 February 2007, A/HRC/4/18, Annex 1. The Basic Principles and Guidelines are the result of an International Workshop on Forced Evictions organised by the Special Rapporteur together with the German Federal Foreign Office and the German Institute for Human Rights, Berlin, June 2005. 
Comment No. 7. For instance, after an eviction, the state or other parties responsible have an immediate obligation to provide just compensation and sufficient alternative accommodation, or restitution when feasible. ${ }^{35}$ Furthermore, at the very minimum, regardless of the circumstances and without discrimination, the government must ensure that evicted persons or groups, especially those who are unable to provide for themselves, have safe and secure access to:

(a) essential food, potable water and sanitation; (b) basic shelter and housing; (c) appropriate clothing; (d) essential medical services; (e) livelihood sources; (f) fodder for livestock and access to common property resources previously depended upon; and (g) education for children and childcare facilities. $^{36}$

States are also required to ensure that members of the same extended family or community are not separated as a result of eviction; and ensure equal participation of women in all planning services and in the distribution of basic services and supplies. $^{37}$

The UN Special Rapporteur on adequate housing has urged states to incorporate the Basic Principles and Guidelines into national laws and policies. ${ }^{38}$ These guidelines would be very useful for South Africa as recent evictions, especially in the inner city of Johannesburg, are development-related. As part of the City of Johannesburg's (the Municipality) effort to mould Johannesburg into an 'African World Class City', in 2003 it launched its Inner City Regeneration Strategy (ICRS). The strategy involves, inter alia, the identification of 'bad buildings' (urban slums) with the intention of closing them down. Thousands of desperately poor people are forced to illegally occupy such buildings-close to basic services and livelihood opportunities-because they cannot afford accommodation on the private residential housing market or afford access to the urban social housing units. Most of these poor people have either no income whatsoever or earn less than R1,000 per month. ${ }^{39}$ Closing down these buildings implies the eviction of large numbers of desperately poor people with little effective notice and without the provision of alternative accommodation. ${ }^{40}$ The eviction applications are often moved on an urgent basis, using apartheid-era laws and regulations, with as little as

35 Ibid. at para. 52.

36 Ibid.

37 Ibid. at paras $52-3$.

38 See Report of the UN Special Rapporteur on adequate housing as a component of the right to an adequate standard of living, Miloon Kothari, 5 February 2007, A/HRC/4/18 at paras 4 and 33(d).

39 See generally, COHRE, Any Room for the Poor? Forced Evictions in Johannesburg, South Africa (2005) at 48 and 56, available at: http://cohre.org/view_page.php?pageid=120\#235 [last accessed 22 November 2007].

40 Wilson, 'A New Dimension to the Right to Housing' (2006) 7 ESR Review 9 at 10. 
10 days between the Municipality filing its eviction papers and an eviction order being granted. Hence, the eviction applications are often unopposed, since occupiers of bad buildings are usually all people lacking in resources, and are unable to access quality legal representation. South African courts, as well as courts in other countries, would therefore be well advised to take cognisance of the Basic Principles and Guidelines and other international standards on evictions in addressing the issue of development-related evictions. ${ }^{41}$

\section{Housing Rights and Evictions in South Africa}

\section{A. Historical Context}

Housing rights in South Africa must be understood against the legacy of apartheid and deep social inequality. To a large extent, apartheid laws and policies have contributed to the unremitting occurrence of evictions and the housing crisis in general. The apartheid government had grossly unequal approaches to housing for each race group. Millions of people were arbitrarily evicted on a regular basis from informal settlements as a result of so-called influx control' policies. ${ }^{42}$ The Slums Act 53 of 1934, for instance, was used to evict people on health and safety grounds from the inner City of Johannesburg with the provision of alternative housing only to white slum dwellers; though the evictions affected all races. ${ }^{43}$ The Group Areas Act 41 of 1950 and its succeeding Acts resulted in people, particularly blacks, being evicted from their homes without any compensation and being relocated to remote, racially defined areas that deprived them of work and educational opportunities. The Prevention of Illegal Squatting Act 52 of 1951 (PISA) allowed landowners to demolish structures on their land and evict people without a court order. In addition, housing subsidy schemes were racially divided, poorly targeted and inadequately funded. ${ }^{44}$

Despite the abolition of influx control in the mid-1980s and the introduction of new policies and approaches with regard to housing in post-apartheid South Africa, apartheid's legacy remains strongly tenacious. ${ }^{45}$ With reference

41 Recently, occupiers of 'bad buildings' have challenged several aspects of the City's practice of forced evictions, which is discussed subsequently. The amici curiae (the Community Law Centre and the Centre on Housing Rights and Evictions) in their submission brought the Court's attention to the Basic Principles and Guidelines.

42 Brand 'Introduction to Socio-Economic Rights in South Africa', in Brand and Heyns (eds) Socio-Economic Rights in South Africa (Pretoria: University Law Press, 2005) 1 at 30.

43 COHRE, supra n. 39 at 14-15. The study captures the extent and nature of Johannesburg inner city evictions and the lives of people living in 'bad buildings'.

44 Chenwi, 'Housing Rights', in Khoza (ed.), The Resource Book, Socio-Economic Rights in South Africa, 2nd edn (University of the Western Cape, Community Law Centre, 2007) at 234-5.

45 Opening address by the Minister of Housing, L.N. Sisulu, at the Housing Indaba, Cape Town, 22 September 2005, available at: http://www.info.gov.za/speeches/2005/0509 2615451007.htm [last accessed 22 November 2007]. 
to the historical and social context of homelessness, the Constitutional Court has described this legacy as follows:

The problem of homelessness is particularly acute in our society. It is a direct consequence of apartheid urban planning which sought to exclude African people from urban areas, and enforced this vision through policies regulating access to land and housing which meant that far too little land and too few houses were supplied to African people. The painful consequences of these policies are still with us eleven years into our new democracy, despite government's attempts to remedy them. The frustration and helplessness suffered by many who still struggle against heavy odds to meet the challenge merely to survive and to have shelter can never be underestimated. The fact that poverty and homelessness still plague many South Africans is a painful reminder of the chasm that still needs to be bridged before the constitutional ideal to establish a society based on social justice and improved quality of life for all citizens is fully achieved. ${ }^{46}$

At present, urban and peri-urban squatting, the growth of and overcrowding in informal settlements and homelessness remain a problematic reality. Due to inadequate housing, the most socially, economically, environmentally and politically disadvantaged and vulnerable sectors of the society, including the poor, women and children, who are engaged in a daily struggle to survive, are forced to illegally occupy land and abandoned buildings, resulting in evictions that render them homeless.

Although the scale of evictions at present is smaller than during apartheid, the problem is still relentless. The sad reality is that these evictions take place despite the country's progressive housing laws, policies and programmes. Hence, any legislation that authorises the eviction of poor people from their homes, even on justifiable grounds, must be scrutinised and interpreted in the light of the constitutional aim of addressing this historical legacy.

\section{B. Legal Context}

The Constitution recognises the injustices of the past and aims to heal historical divisions and establish a society based on democratic values, social justice and fundamental human rights. ${ }^{47}$ Its extensive protection of socio-economic rights represents a commitment to overcome apartheid's legacy.

47 Preamble to the Constitution. 
The Constitution aims to address the housing and eviction crisis as it guarantees the right to have access to adequate housing. Section 26 of the Constitution states as follows:

(1) Everyone has the right to have access to adequate housing.

(2) The state must take reasonable legislative and other measures, within its available resources, to achieve the progressive realisation of this right.

(3) No one may be evicted from their home, or have their home demolished, without an order of court made after considering all the relevant circumstances. No legislation may permit arbitrary evictions. ${ }^{48}$

It is important to note that Section 26 does not create an entitlement to immediate implementation free of charge but an entitlement to have 'access' to adequate housing, which the state must progressively realise through reasonable legislative and other measures. This could limit the judicial protection of the right. However, the Constitutional Court has noted that a right of access to housing, as distinct from the right to adequate housing recognised in the ICESCR, recognises that housing entails more than just 'bricks and mortar'. For a person to have access to adequate housing, there must be land, appropriate services such as the provision of water and the removal of sewage, and the financing of all these, including the building of the house itself. ${ }^{49}$

Section 26 is aimed at creating a dispensation in which every person has adequate housing and in which the state may not interfere with such access unless it would be justifiable to do so. As observed by the Constitutional Court,

Section 26 must be seen as making that decisive break from the past. It emphasises the importance of adequate housing and in particular security of tenure in our new constitutional democracy. The indignity suffered as a result of evictions from homes, forced removals and the relocation to land often wholly inadequate for housing needs has to be replaced with a system in which the State must strive to provide access to adequate housing for all and, where that exists, refrain from permitting people to be removed unless it can be justified. ${ }^{50}$ child the right to basic shelter; Section 35(2)(e), requiring adequate accommodation to be provided to detained persons, including sentenced prisoners at state expense; Section 25(5), directing the state to 'take reasonable legislative and other measures, within its available resources, to foster conditions which enable citizens to gain access to land on an equitable basis'; and Section 25(6), further protecting vulnerable groups by reinforcing security of tenure. Section 25 is relevant for the protection of housing rights and the protection against arbitrary evictions, because realising the right of access to adequate housing requires available land and 'the stronger the right to land, the greater the prospect of a secure home': see Port Elizabeth Municipality v Various Occupiers 2004 (12) BCLR 1268 (CC) at para. 19.

49 Government of the Republic of South Africa and Others v Grootboom, supra n. 17 at para. 35.

50 Jaftha $v$ Schoeman and Others; Van Rooyen $v$ Stoltz and Others 2005 (1) BCLR 78 (CC) at para. 29. 
This section must, therefore, be interpreted in the light of the values and interests it seeks to promote in the new constitutional democracy and the historical injustices it aims to rectify.

The Constitutional Court has interpreted Section 26(1) as placing, at the very least, a negative obligation on the state, other entities and persons to desist from preventing or impairing the right of access to adequate housing. ${ }^{51}$ Hence, any measure that removes from people their pre-existing access to adequate housing limits the right to housing in the Constitution. ${ }^{52}$

Section 26(2) of the Constitution speaks to the positive obligation imposed upon the state. It qualifies the right to have access to adequate housing, by placing a duty on the state to adopt appropriate measures to ensure that this right is effectively enforced on a progressive basis. The state's positive obligation is discussed further below. However, it should be noted that it is not only the state that is responsible for the provision of housing, but also individuals and other agents within the society must be enabled by legislative and other measures to provide housing. Thus, the state's duty is to create the conditions for access to adequate housing for people at all economic levels. ${ }^{53}$

The negative obligation in Section 26(1) is reiterated in Section 26(3) of the Constitution that prohibits arbitrary evictions. The latter was adopted to address the injustices and unfair evictions in the past (during apartheid). It therefore evinces special constitutional regard for a person's home. According to the Constitutional Court,

[Section 26(3)] acknowledges that a home is more than just a shelter from the elements. It is a zone of personal intimacy and family security. Often it will be the only relatively secure space of privacy and tranquillity in what (for poor people in particular) is a turbulent and hostile world. Forced removal is a shock for any family, the more so for one that established itself on a site that has become its familiar habitat. ${ }^{54}$

Subsection (3) has three principal components: (i) a guarantee against the eviction of persons from their homes or the demolition thereof without an order of court; (ii) the requirement that courts should consider 'all relevant circumstances' before granting an eviction order; and (iii) a prohibition against the passing of legislation that permits arbitrary evictions. An eviction may be arbitrary in two respects - procedurally arbitrary because the procedure was unfair and substantively arbitrary because there are no sufficient reasons for the eviction. ${ }^{55}$ Section $26(3)$ sets out the procedural aspect by explicitly stating

51 Government of the Republic of South Africa and Others v Grootboom, supra n. 17 at para. 34.

52 Jaftha $v$ Schoeman and Others; Van Rooyen v Stoltz and Others, supra n. 50 at para. 34.

53 Government of the Republic of South Africa and Others v Grootboom, supra n. 17 at para. 36.

54 Port Elizabeth Municipality v Various Occupiers, supra n. 48 at para. 17.

55 See First National Bank of SA Ltd t/aWesbank v Commissioner, South African Revenue Service and Another 2002 (4) SA 768 (CC) at paras 67 and 99-100, which concerned property rights. 
that evictions and demolitions of homes can only occur on the authority of the court after considering all the relevant circumstances. Substantive aspects, such as fair and effective notice of eviction proceedings, are dealt with in other legislation discussed below.

Section 26(3) of the Constitution gave rise to the passing of the Extension of Security of Tenure Act 62 of 1997 (ESTA). In its preamble, ESTA acknowledges that apartheid discriminatory laws and practices have left many South Africans with no secure tenure of their homes and the land that they use, rendering them vulnerable to unfair eviction. It further recognises the need to ensure that occupiers-persons residing on land which belongs to another person-are not further prejudiced; and for law to regulate the eviction of vulnerable occupiers from land in a fair manner, while recognising the right of landowners to apply to a court for an eviction order in appropriate circumstances. In line with the Constitution, Section 9 of ESTA requires a landowner to get a court order before evicting unlawful occupiers. However, the problem with ESTA is that it provides protection only to unlawful occupiers who previously had some form of consent or right to occupy the land in question.

The exclusion of occupiers, who did not have previous consent or right to occupy the land in question from ESTA, resulted in the enactment of the Prevention of Illegal Eviction from and Unlawful Occupation of Land Act 19 of 1998 (PIE). ${ }^{56}$ The PIE was adopted as a means of overcoming abuses and ensuring that evictions take place in a manner that is consistent with the values of the new constitutional dispensation. The PIE decriminalises squatting. It provides a framework within which unlawful occupation can be prevented and at the same time ensuring dignified and individualised treatment of unlawful occupiers with special consideration for the most vulnerable. It reinforces the court order requirement under Section 26(3) of the Constitution. Hence, an eviction may only take place under judicial control.

The eviction process is now subject to a number of procedural and substantive requirements, as PIE provides some legislative texture to guide the courts in determining the approach to eviction required by Section 26(3) of the Constitution. ${ }^{57}$ For instance, Section $4(6)$ of the PIE requires that before granting an eviction order, the courts must be of the opinion that it is just and equitable to do so, after considering all the relevant circumstances, including the rights and needs of the elderly, children, disabled persons and households headed by women'. Section 4(7) goes further to state that the court must consider, where an occupier has occupied the land in question for more

56 The PIE repealed the PISA under which, once it was determined that the occupiers had no permission to occupy the land, they faced summary eviction and were liable for criminal prosecution.

57 Port Elizabeth Municipality v Various Occupiers, supra n. 48 at para. 24. 
than six months, 'whether land has been made available or can reasonable be made available by a Municipality or other organ of state or other landowner for the relocation of the unlawful occupier'. In addition, Section 6 of PIE dealing with eviction proceedings instituted by an organ of state lists the following circumstances to be considered in deciding whether to grant an eviction order: the circumstances under which the unlawful occupier occupied the land and erected the building or structure; the period the unlawful occupier and his or her family have resided on the land in question; and the availability to the unlawful occupier of suitable alternative accommodation or land. ${ }^{58}$

Other laws that have been enacted to give effect to Section 26 of the Constitution include the following: the Restitution of Land Rights Act 22 of 1994, which protects occupiers of land who have instituted a restitution claim; the Land Reform (Labour Tenants) Act 3 of 1996, which protects occupiers of agricultural (rural) land; the Interim Protection of Informal Land Rights Act 31 of 1996, which protects occupiers of land in terms of informal land rights; and the Rental Housing Act 50 of 1999, which protects the housing rights of occupiers of residential property.

These laws form a web of protection that has considerably improved the position of previously vulnerable and marginalised groups whose legal rights to access land and housing were weak or non-existent. ${ }^{59}$ One of the challenging questions of South Africa's democracy has been how to translate these laws and policies into reality-resulting in safe, secure and affordable living conditions for the poor and vulnerable. The courts play a crucial role in this regard; ensuring greater protection for those faced with evictions. This has been done through, inter alia, elaborating on the state's constitutional obligation to ensure access to adequate housing for all and the constitutional requirement to consider relevant circumstances.

58 It should be noted that PIE is currently under revision and the proposed amendments, among others, seek to repeal the distinction between persons occupying land for less than six months and persons occupying land for more than six months, as the distinction constitutes unequal protection of a person's right not to be evicted as afforded by Section 26(3) of the Constitution. One of the problematic aspects of the amendments is the proposed narrowing of the ambit of PIE to exclude some unlawful occupiers, for instance ex-tenants and ex-mortgagors, from the protection of PIE, despite the fact that they are not currently protected by other legislation (see the Prevention of Illegal Eviction from and Unlawful Occupation of Land Amendment Bill 2006, South African Government Gazette No. 29501, 22 December 2006). Generally, since its inception, landowners have viewed PIE with disfavour contending that it interferes with their common law right to instantly evict unlawful occupiers from their land, as the procedural and substantive requirements of PIE make it difficult, if not impossible, for them to evict such occupiers (see generally, Christmas, 'Proposed Amendments to the Prevention of Illegal Eviction from and Unlawful Occupation of Land Act: A Setback for Vulnerable Occupiers' (2004) 5 ESR Review 6. 


\section{The State's Obligation to Ensure Access to Adequate Housing for All}

The state has a constitutional obligation to 'respect, protect, promote and fulfil' the right of access to adequate housing. ${ }^{60}$ At the very least, this implies that the state adopts measures aimed at realising this right for all, including those faced with evictions. The extent of the state's duty is qualified by three key elements, set out in Section 26(2) of the Constitution: (i) the obligation to 'take reasonable legislative and other measures'; (ii) 'to achieve the progressive realisation' of the right; and (iii) 'within available resources'.

\section{A. Reasonable Legislative and Other Measures}

The state has an obligation to take steps aimed at realising the right to adequate housing for people from all economic spheres, and the steps taken must be reasonable. The Constitutional Court has described the standards against which to evaluate the reasonableness of the state's measures. The Court observed that the state could adopt a wide range of measures to meet its obligations. But the question that remains to be answered is whether the measures are reasonable. In this regard, the Court observed that, in reviewing compliance with the state's obligation, a court 'will not enquire whether other more desirable or favourable measures could have been adopted, or whether public money could have been well spent'.61

In order for measures to be reasonable, they must aim at the effective and expeditious progressive realisation of the right in question, within the states available resources for implementation. The measures must be comprehensive, coherent, inclusive, balance, flexible, transparent, be properly conceived and properly implemented, and make short, medium and long-term provision for those in desperate need or in crisis situations. The measures must further clearly set out the responsibilities of the different spheres of government and ensure that financial and human resources are available for their implementation.

As can be deduced from the above standards, the formulation of a housing programme is only the first stage in meeting the state's obligation, as 'an otherwise reasonable programme that is not implemented reasonably will not constitute compliance with the state's obligations. ${ }^{62}$ In addition, the programme must be tailored to the particular context in which it is to apply - what may be appropriate in a rural area may not be appropriate in an urban setting. ${ }^{63}$ A reasonable programme must also take account of different economic levels in the society, including those who can afford to pay for housing and those

60 Section 7(2), Constitution.

61 Government of the Republic of South Africa and Others v Grootboom, supra n. 17 at para. 41.

62 Ibid. at para. 42.

63 Ibid. at para. 37. 
who cannot. Of particular importance is the requirement that short, medium and long-term provision must be made for housing needs. Measures aimed at realising the right to have access to adequate housing, to be reasonable, cannot ignore those whose housing needs are the most urgent and whose ability to enjoy all human rights is most in peril.

In the Grootboom case, although the state had a plan for the progressive realisation of the right to have access to adequate housing and major achievements had been made, there was a major flaw in its housing programme in that it did not make reasonable provision for those in desperate need of housing - those with no roof over their head, no access to land, and who were living in intolerable conditions or crisis situations. Consequently, the Court had to consider whether the government was obliged under Section 26 of the Constitution to make provision for emergency housing for the respondents and others in similar circumstances. It held that the state's programme could not be said to be reasonable, as it does not cater for those desperately in need of access to housing in the Cape Metropolitan area. The Court ordered the state to adopt, implement and supervise a comprehensive and coordinated programme that addressed effectively the situation of those desperately in need of housing. ${ }^{64}$

The state's constitutional obligation to make short-term provision for people in crisis and desperate situations was also considered in the case of City of Cape Town $v$ Rudolph and Others. ${ }^{65}$ The case concerned an application brought by the City of Cape Town (applicant) for the eviction of residents of Valhalla Park (respondents), an area within the jurisdiction of the applicant. Some of the respondents had been placed on the housing waiting list of the applicant as far back as ten years ago. As a result of the over-crowded, intolerable conditions under which they were living at the time, they decided to move onto vacant land that was owned by the applicant. The applicant subsequently applied to the High Court for an order of eviction against them. ${ }^{66}$

64 Following the Grootboom judgment, the Emergency Housing Programme was adopted (National Department of Housing, National Housing Programme: Housing Assistance in Emergency Circumstances, April 2004, available at: http://www.housing.gov.za/Content/legis lation.policies [last accessed 22 November 2007]). The programme aims to assist groups of people faced with urgent housing problems, such as evictions or threatened evictions, by providing temporary assistance in the form of municipal grants. Such grants would enable the Municipality to respond to emergencies by providing secure access to land, boosting infrastructure and basic services, and improving access to shelter through voluntary relocation and resettlement. Municipalities are encouraged to assess in advance the emergency housing needs in their areas and take concrete steps to address them. Sadly, the implementation of the emergency programme at the provincial level has been very slow. For further discussion of the Grootboom case, see generally Wesson, 'Equality and Social Rights: An Exploration in Light of the South African Constitution' (2007) Public Law 748.

652003 (11) BCLR 1236 (C).

66 Ibid. at 1250 I and $1251 \mathrm{~A}-\mathrm{F}$. The application was based on the common law, as the applicants contended that the PIE did not apply to the respondents. In the alternative, the applicant sought urgent relief in terms of the provision on urgent eviction applications in the PIE; 
The respondents not only opposed the application, but also brought a counter application on the basis that the applicant's housing policies and programmes had failed to fulfil its constitutional and statutory obligations to give effect to their right of access to adequate housing guaranteed in Section 26 of the Constitution. In particular, they argued that the applicant had failed to give effect to the Grootboom judgment - to make short-term provision for people in Valhalla Park who were in crisis and desperate situations.

The application for the eviction of the respondents was dismissed and the Court found, with regard to the counter application, that the City had failed to provide any short-term programmes that could meet the housing needs of the residents of Valhalla Park, an 'unacceptable disregard for the Constitutional Court - and therefore for the Constitution itself'. ${ }^{67}$ The Court then ordered the City of Cape Town to comply with its constitutional obligations to make shortterm provision for people in Valhalla Park who were in crisis and desperate situations. The City was further required to produce a report within four months, detailing what steps it had taken to ameliorate the situation, and what future policies and programmes would be put in place to this end. ${ }^{68}$

It is important to note that by adopting a reasonableness review approach, the Constitutional Court has, for the time being, turned a deaf ear to the minimum core obligation approach. The amici curae in the Grootboom case requested that the right to have access to adequate housing in the Constitution be interpreted as encompassing an immediate enforceable minimum core obligation on the state. ${ }^{69}$ But the Court declined to do so stating that it is not possible to determine a minimum threshold for the progressive realisation of the right to adequate housing without first identifying the needs and opportunities for the enjoyment of such a right. ${ }^{70}$ This difficulty, as the Court noted, is compounded by the fact that groups are differently situated and have varying social needs. ${ }^{71}$ Nonetheless, the Court acknowledged that 'there may be cases where it may be possible and appropriate to have regard to the content of a minimum core obligation to determine whether the

and challenged the PIE's constitutional validity on the ground that it violates the rights of property owners. However, the Cape High Court dismissed the challenge to the constitutionality of the PIE, holding that it was applicable.

67 Ibid. at 1275C-D, 1280H-J and 1281A-B.

68 Ibid. at $1281 \mathrm{C}$.

69 Government of the Republic of South Africa and Others v Grootboom, supra n. 17 at paras 27-9. The minimum core approach is aimed at protecting the most vulnerable groups of society. Generally, the approach involves identifying such subsistence levels in respect of each socioeconomic right and insisting that the provision of 'core' goods and services enjoys immediate priority. It thus represents a 'floor' of immediately enforceable entitlements from which progressive realisation should proceed. See Pieterse, 'Resuscitating Socio-Economic Rights: Constitutional Entitlements to Health Care Services' (2006) 22 South African Journal on Human Rights 473 at 481.

70 Government of the Republic of South Africa and Others v Grootboom, supra n. 17 at para. 32.

71 Ibid. at paras $32-3$. 
measures taken by the State are reasonable. ${ }^{72}$ Even if the Grootboom case was one of such cases, the Court still could not do so because, as it stated, it did not have sufficient information to determine what would comprise the minimum core obligation with regard to the right to have access to adequate housing. ${ }^{73}$

The reasonableness approach has not been without criticisms, including the fact that it creates a number of difficulties for the enforcement of socio-economic rights by individuals and groups living in poverty. This difficulty arises from the fact that the applicants would have to marshal a considerable array of economic and expert evidence to convince the court that the government's social policy is unreasonable, which poor applicants might not be able to do. ${ }^{74}$

Notwithstanding, the advantage of the reasonableness approach is that it gives wide latitude to the political branches of government to make the appropriate policy choices to meet its socio-economic rights obligations, with the court's role being to determine whether they fall within the bounds of 'reasonableness; thus addressing separation of powers concerns. Also, the fact that the reasonableness approach is determined on a case-by-case basis and is context sensitive is an advantage in the sense that it creates the on-going possibility of challenging socio-economic deprivations in the light of changing historical, social and economic contexts. ${ }^{75}$ Hence, the standard is not exhaustive.

\section{B. Progressive Realisation of the Right}

It is unquestionable that the right to have access to adequate housing cannot be realised immediately. The Constitutional Court has endorsed the CESCR's understanding of the phrase 'progressive realisation'. In General Comment No. 3, the CESCR interpreted the term as follows:

The concept of progressive realization constitutes a recognition of the fact that full realization of all economic, social and cultural rights will generally not be able to be achieved in a short period of time... Nevertheless, the fact that realization over time, or in other words progressively, is foreseen under the Covenant should not be

72 Ibid. at para. 33.

73 Ibid. Later, in Minister of Health and Others v Treatment Action Campaign 2002 (5) SA 721 (CC), the Court was of the view that the minimum core was incompatible with the institutional competencies and role of the courts. It held that 'courts are not institutionally equipped to make the wide-ranging factual and political enquiries necessary for determining what the minimum core standards' should be (at para. 37). This is because, according to the Court, all the state can do is undertake reasonable measures within its available resources to progressively realise the rights.

74 Liebenberg, 'Needs, Rights and Transformation: Adjudicating Social Rights in South Africa' (2005) 6 ESR Review 3 at 6. See also Liebenberg, 'Basic Rights Claims: How Responsive is Reasonableness Review?' (2004) 5 ESR Review 7.

75 Government of the Republic of South Africa and Others v Grootboom, supra n. 17 at paras 43-4 and $82-3$. 
misinterpreted as depriving the obligation of all meaningful content. It is on the one hand a necessary flexibility device, reflecting the realities of the real world and the difficulties involved for any country in ensuring full realization of economic, social and cultural rights. On the other hand, the phrase must be read in the light of the overall objective, indeed the raison dêtre, of the Covenant which is to establish clear obligations for States parties in respect of the full realization of the rights in question. It thus imposes an obligation to move as expeditiously and effectively as possible towards that goal. Moreover, any deliberately retrogressive measures in that regard would require the most careful consideration and would need to be fully justified by reference to the totality of the rights provided for in the Covenant and in the context of the full use of the maximum available resources. ${ }^{76}$

With reference to the above, the Constitutional Court stated that the term bears the same meaning in the Constitution. ${ }^{77}$ The use of the phrase in the Constitution, therefore, does not mean that the state can drag its feet in meeting its duties or providing the necessary measures to realise the right to adequate housing. Any deliberate retrogressive measures would constitute an infringement of this right. ${ }^{78}$

\section{Within Available Resources}

The rate at which the right to have access to adequate housing is realised and the reasonableness of measures adopted to achieve this goal are governed by the state's available resources. In other words, the availability of resources would always be an important factor in determining what is reasonable in a particular case. The phrase 'within available resources' implies that the obligation placed on the state does not require more than its available resources. ${ }^{79}$

76 General Comment No. 3, supra n. 5 at para. 9.

77 Government of the Republic of South Africa and Others v Grootboom, supra n. 17 at para. 45.

78 See Government of the Republic of South Africa and Others v Grootboom, supra n. 17 at para. 45; Pienaar and Muller, 'The Impact of the Prevention of Illegal Eviction From and Unlawful Occupation of Land Act 19 of 1998 on Homelessness and Unlawful Occupation Within the Present Statutory Framework' (1999) 3 Stellenbosch Law Review 370 at 376.

79 Government of the Republic of South Africa and Others v Grootboom, supra n. 17 at para. 46. It should be noted that in some cases, the Constitutional Court has avoided budgetary issues altogether. For example, in Soobramoney v Minister of Health (KwaZulu Natal) 1998 (1) SA 765 (CC), the Court simply accepted the state's contention that resources were limited. This case concerned a challenge to the resource rationing policy of a state hospital, according to which Soobramoney, who suffered from chronic renal failure, was excluded from a renal dialysis treatment programme due to his general state of health and the fact that his condition was irreversible. However, in cases where budgetary issues could not be avoided, the Court has required the state to persuade it of its financial constraints. For example, in Minister of Health and Others v Treatment Action Campaign, supra n. 73, and Khosa v Minister of Social Development (2004) 6 SA 505 (CC) at paras 120 and 133, the Court rejected the state's 
Resources here refer to both the resources within the state and those available from the international community through international cooperation and assistance. $^{80}$

\section{The Requirement to Consider Relevant Circumstances}

Section 26(3) of the Constitution, as mentioned earlier, requires courts to consider 'all relevant circumstances' before deciding whether an eviction should be ordered. The subsection does not specify the relevant circumstances to be considered. However, the procedural aspect contemplated in Section 26(3) has been elaborated upon through legislation as seen above and through judicial interpretation as discussed subsequently. As mentioned above, PIE for instance, provides substantive and procedural requirements that guide the courts in interpreting Section 26(3) of the Constitution.

Initially, the courts did not deem it necessary to define what circumstances would be regarded as 'relevant' in an eviction context. In Ross $v$ South Peninsula Municipality, the High Court stated that it was beyond the scope of the appeal to consider what circumstances will be regarded as 'relevant' in an eviction context. ${ }^{81}$ However, it stated further that some guidance be sought from Sections 4(6) and 4(7) of PIE dealing with the protection of the rights of the elderly, children, disabled persons and households headed by women in an eviction context. The courts' obligation to consider relevant circumstances and the fact that PIE provides some guidance as to the sort of circumstances a court might take into consideration was subsequently confirmed in MEC for Business Promotion and Property Management, Western Cape v Matthyse. ${ }^{82}$ In this case, the Court stated that the aim of Section 26(3) was to mitigate the harshness of an eviction, meaning that a court can stay or suspend eviction orders if it is fair and reasonable to do so under the circumstances. Later, the Supreme Court of Appeal was of the view that for circumstances to be relevant

contention that it did not have the requisite resources. The TAC case concerned a challenge to the state's policy on the prevention of mother-to-child transmission of HIV, which was challenged as inconsistent with the right to have access to health care services. The Khosa case concerned a challenge to the provisions of the Social Assistance Act 59 of 1992 for excluding people with permanent residence status from accessing social assistance.

80 De Vos, supra n. 59 at 100.

812000 (1) SA 589 (C) at 591D. This case was an appeal from the decision of the Magistrate's Court. It concerned the impact of Section 26(3) on the common law right of eviction and the extent to which it placed an onus on the plaintiff to allege relevant circumstances in addition to those that were relevant at common law. In this case, the Municipality was seeking an eviction order against Mrs Ross and her children from a flat that she had leased from the Municipality.

822000 (1) All SA 377 (C). This case concerned an eviction application against a number of families, all former employees of the Western Cape provincial government. The units in which they lived in were part of their employee benefits, which was now required by the government for new development. 
for the purposes of Section 26(3), they must be legally relevant. ${ }^{83}$ This means the circumstances determined by the relevant law. Subsequently, the Supreme Court of Appeal added that the circumstances under PIE (mentioned under '3B Legal Context' Section above) should be taken into account. ${ }^{84}$

The Constitutional Court observed that the inclusion of the requirement to consider all relevant circumstances serves a clear constitutional purpose. According to the Court,

The statement in the Constitution that the courts must do what courts are normally expected to do, namely, take all relevant factors into account, would appear otiose (superfluous), even odd. Its use in s 26(3), however, serves a clear constitutional purpose. It is there precisely to underline how non-prescriptive the provision is intended to be. The way in which the courts are to manage the process has, accordingly, been left as wide open as constitutional language could achieve, by design and not by accident, by deliberate purpose and not by omission. ${ }^{85}$

It is not easy to classify the multitude of places and relationships involved. This is precisely why, even though unlawfulness is established, the eviction process is not automatic and why the courts are called upon to exercise a broad judicial discretion on a case by case basis. ${ }^{86}$

This was in the PE Municipality case, which concerned an eviction application by the state (in particular, the Port Elizabeth Municipality) against 68 people, including 23 children (occupiers), who had illegally occupied private undeveloped land within the Municipality's jurisdiction. The application was based on Section 6 of PIE, which states that an organ of state may institute proceedings for the eviction of an unlawful occupier within its area of jurisdiction. The occupiers had been living on the land for periods ranging from two to eight years. Most of them had moved onto the land after being evicted from previously occupied land. The occupiers indicated that they were willing to vacate the property, provided that they were given suitable alternative land to which they could move. However, the occupiers had rejected a proposal made by the Municipality that they move to identified land on the basis of lack of security of tenure, thus making them liable to further eviction. The Municipality argued that giving them alternative land would be preferential treatment; it would disrupt the existing housing programme and would be 'queue-jumping' by the occupiers. The Municipality did not engage in any discussions with the occupiers to identify their particular circumstances or needs. 
As noted further by the Court in this case, one of the circumstances in deciding whether an eviction would be just and equitable would be whether mediation has been tried. ${ }^{87}$ The Court, while observing that the state's duties extend beyond the development of housing schemes to treating those within their jurisdiction with respect, stated that 'where the need to evict people arises, some attempts to resolve the problem before seeking a court order will ordinarily be required. ${ }^{88}$ It went further to add that 'a court involved in future litigation involving occupiers should be reluctant to accept that it would be just and equitable to order their eviction if it is not satisfied that all reasonable steps had been taken to get an agreed, mediated solution, ${ }^{89}$ The extent to which serious negotiations have taken place with equality of voice for all concerned is therefore a relevant factor to be considered in determining whether it is just and equitable to grant an eviction order. In the Grootboom case, as well, emphasis was placed on the need for meaningful consultation with individuals and communities affected by housing development. ${ }^{90}$

The importance of mediation as affirmed in PE Municipality was recently emphasised in Lingwood Michael and Another v The Unlawful Occupiers of R/E of Erf 9 Highlands. ${ }^{91}$ The Court noted the necessity and importance of parties involved in litigation instituted under PIE to engage in mediation in an endeavour to achieve mutually acceptable solutions. ${ }^{92}$ Since the parties in the case had not engaged in any negotiations or attempted any mediation in an attempt to exploring (sic) all reasonable possibilities of securing suitable alternative accommodation or land and/or of achieving solutions mutually acceptable to the parties', the Court accordingly refused an eviction order and postponed the matter sine die, and ordered the joinder of the City of Johannesburg (the Municipality) by virtue of its constitutional and statutory duties and the commencement of mediation. ${ }^{93}$ The Constitutional Court has made a similar order in the case of Occupiers of 51 Olivia Road, Berea Township and 197 Main Street, Johannesburg $v$ City of Johannesburg and Others. ${ }^{94}$

87 Ibid. at para. 45.

88 Ibid. at para. 56.

89 Ibid. at para. 61.

90 Government of the Republic of South Africa and Others v Grootboom, supra n. 17 at para. 84.

91 Case No. 2006/16243 (WLD), 2007, unreported, which concerned a private eviction brought in terms of PIE.

92 Ibid. at para. 33.

93 Ibid. at para. 37-8.

94 Case No: CCT 24/07, Interim Order, 30 August 2007. This case raised the difficult issue of how to reconcile respect for the inadequate accommodation which people living on the margins (desperately poor people) have managed to secure, and the statutory powers and duties of local authorities to ensure that conditions of accommodation do not constitute a threat to the safety of these persons. It concerned several applications in which the Municipality sought the eviction of over 300 people (the occupiers) from six properties in the inner city of Johannesburg. The Municipality (the applicant) justified the eviction on the basis of Section 12(4)(b), National Building Regulations and Building Standards Act 103 of 1977 (NBRA), which gives it statutory powers and duties to prevent dangerous living conditions in its area of jurisdiction. The occupiers opposed the eviction application, and urged the Court to declare 
The Court ordered the City of Johannesburg and the applicants to engage with each other meaningfully and as soon as it was possible in an effort to resolve the differences and difficulties raised in the case in the light of the values of the Constitution, the constitutional and statutory duties of the Municipality and the rights and duties of the citizens concerned. The Court further requested the parties to file affidavits after over a month reporting the results of their engagement, which it would take into account in the preparation of its judgment.

Another relevant circumstance that the Court in PE Municipality looked at was the availability of suitable alternative accommodation. In this regard, the Court stated that the real question in the case was whether the Municipality had considered seriously or at all the request of the occupiers that they be provided with suitable alternative land upon which they could live 'without fear of eviction' until provided with housing by the Municipality. ${ }^{95}$

The Court then found that it was not just and equitable to evict the occupiers given the following: (i) the lengthy period during which the occupiers had lived on the land in question; (ii) the fact that there was no evidence that either the Municipality or the owners of the land needed to evict the occupiers in order to put the land to some other productive use; (iii) the absence of any significant attempts by the Municipality to listen to and consider the problems of this particular group of occupiers; and (iv) the fact that this was a relatively small group of people who appeared to be genuinely homeless and in need. ${ }^{96}$

In a nutshell, the PE Municipality case highlights a number of circumstances to be considered when deciding on whether or not to grant an eviction order. These include: (i) the manner in which the occupation was effected; (ii) the duration of the occupation; (iii) the availability of suitable alternative accommodation or land; (iv) reasonableness of offers made in connection with suitable alternative accommodation or land; (v) the timescales proposed relative to the degree of disruption involved; (vi) the willingness of the occupiers to respond to reasonable alternatives put before them; (vii) the extent to

the practice of securing evictions by reliance on the NBRA unconstitutional, and also sought a declaration that the Municipality's housing programme fails to comply with its constitutional and statutory obligations, as it does not cater for those in desperate need. The occupiers also sought an interdict preventing the Municipality from seeking to evict them until suitable alternative accommodation was provided, bringing the Municipality into compliance with its constitutional obligations. The High Court interdicted the Municipality from seeking to evict the occupiers pending the implementation of a comprehensive housing programme, or until such time as suitable adequate alternative accommodation could be provided. However, the Supreme Court of Appeal upheld the Municipality's right in terms of the NBRA to evict residents of 'bad buildings' when it deems it necessary for health and safety reasons, which is not dependent upon it being able to provide alternative accommodation to the occupants. The occupiers then appealed to the Constitutional Court. This case is discussed further below: see City of Johannesburg Rand Properties (Pty) Ltd and Others, infra n. 120 and infra n. 123.

95 Port Elizabeth Municipality v Various Occupiers, supra n. 48 at para. 58.

96 Ibid. at para. 59. 
which serious negotiations have taken place with equality of voice for all concerned; and (viii) the gender, age, occupation or lack thereof and state of health of those affected. ${ }^{97}$

An additional relevant circumstance that was highlighted in Grootboom is the manner of execution of the eviction order, that is, whether it was executed humanely. In this regard, the Court held that the state had an obligation to ensure, at the very least, that the eviction was executed humanely. The fact that the eviction was carried out a day early and that the possessions and building materials of the respondents (the unlawful occupiers) were destroyed and burnt amounted to a breach of the negative obligation embodied in the right of access to adequate housing recognised under Section 26(1) of the Constitution. $^{98}$

Furthermore, the interests of surrounding communities as well as the negative impact of 'land gaps' on investor-confidence in the country, and the right of landowners (discussed subsequently), have been regarded by the courts as relevant factors. ${ }^{99}$

It is important to note that the above circumstances are not exhaustive, requiring a degree of appreciation of the specific situation of each case. The subsequent paragraphs consider in more detail two of the above relevant circumstances - the availability of alternative accommodation and balancing the various interests involved, in particular, the right to adequate housing of those faced with eviction and the rights of landowners. The former factor is usually a critical issue when it comes to evictions as, more often than not, evictions result in homelessness. The latter factor involves balancing the constitutional rights of landowners and unlawful occupiers, as it is also an important duty of the court to ensure that it protects not just the interest of unlawful occupiers but also that of the landowners.

\section{A. The Availability of Suitable Alternative Accommodation or Land}

The importance of the availability of alternative accommodation arises not just from the constitutional guarantee to have access to adequate housing and the related state duty but also from the right to human dignity, ${ }^{100}$ as the state has an obligation to ensure that evictions are executed humanely. This factor is therefore relevant, at the very least, to the question whether an eviction may

97 Ibid. at paras 25-30, 33 and 53.

98 Government of the Republic of South Africa and Others v Grootboom, supra n. 17 at para. 88.

99 Groengras Eiendomme (Pty) Ltd v Elandsfontein Unlawful Occupants and Others 2002 (1) SA 125 (T) at para. 32. Other circumstances considered in this case include: the blatant invasion of the land, the short duration of the stay on the property, the probability that the occupants would be able to return to where they had come from, and the irreversible loss to the applicants should the eviction order be granted.

100 Section 10 of the Constitution provides that 'everyone has inherent dignity and the right to have their dignity respected and protected'. 
be humanely executed. In this regard, the Supreme Court of Appeal has stated as follows:

To the extent that we are concerned with the execution of the court order, Grootboom made it clear that the government has an obligation to ensure, at the very least, that evictions are executed humanely. As must be abundantly clear by now, the order cannot be executed - humanely or otherwise - unless the state provides some land. ${ }^{101}$

In similar vein, the CESCR has stated that, prior to carrying out any evictions, and particularly those involving large groups, states must ensure that all feasible alternatives are explored in consultation with the affected persons, with a view to avoiding, or at least minimising, the need to use force. ${ }^{102}$ The CESCR went further to state:

Evictions should not result in individuals being rendered homeless or vulnerable to the violation of other human rights. Where those affected are unable to provide for themselves, the State party must take all appropriate measures, to the maximum of its available resources, to ensure that adequate alternative housing, resettlement or access to productive land, as the case may be, is available. ${ }^{103}$

In the South African context, there is no unqualified constitutional duty on the state to ensure that in no circumstances should an eviction take place unless alternative suitable accommodation or land is made available. However, as a signatory to the Habitat Agenda, South Africa has committed itself to providing, as appropriate, alternative solutions when evictions are unavoidable. $^{104}$

The Constitutional Court has been at pains in all its judgments in eviction cases in emphasising the provision of alternative accommodation for vulnerable groups (those in desperate need), even if temporary, as a significant factor. It has stated that 'a court should be reluctant to grant an eviction against relatively settled occupiers unless it is satisfied that a reasonable alternative is available, even if only as an interim measure pending ultimate access to housing in the formal housing programme. ${ }^{105}$ Moreover, it has said: 'The availability of suitable alternative accommodation or land is one of the

101 Modderfontein Squatters, Greater Benoni City Council v Modderklip Boedery (Pty) Ltd; President of the Republic of South Africa and Others v Modderklip Boerdery (Pty) Ltd 2004 (8) BCLR 821 (SCA) at para. 26.

102 General Comment No. 7, supra n. 25 at para. 13.

103 General Comment No. 7, supra n. 25 at para. 16.

104 Habitat Agenda, Adopted by the 2nd United Nations Conference on Human Settlements (Habitat II), Istanbul, 1996, at paras 40(n) and 98(b); and Groengras Eiendomme (Pty) Ltd v Elandsfontein Unlawful Occupants and Others, supra n. 99 at para. 28.

105 Port Elizabeth Municipality v Various Occupiers, supra n. 48 at para. 28. 
factors, if not the most important factor for a Court to have regard to in determining whether it is just and equitable to issue an eviction order. ${ }^{106}$

The provision of alternative accommodation is evaluated on a case-by-case basis as it also depends on the number of people, their age, and whether they can provide for themselves. This means that, in some instances, the court may order an eviction where the result is homelessness. These include: where the occupation creates a genuinely urgent or pressing danger; ${ }^{107}$ where a group of homeless people is chosen over another who seek access to the same land; ${ }^{108}$ where the occupation of the land is intended to coerce a state structure into providing housing on a preferential basis; ${ }^{109}$ and the eviction of people living in informal settlements. ${ }^{110}$

However, the provision of alternative accommodation is an important factor to be considered where settled occupiers are to be evicted, especially if they are not at fault, and the result of the eviction will be homelessness. In harmony with the international understanding of the obligation imposed on states to respect and protect human rights, recent South African jurisprudence demonstrates that the duty to respect and protect the right to have access to adequate housing necessarily implies a right to alternative accommodation on eviction, where the evictees are not able to obtain this through their own effort. ${ }^{111}$ It could therefore be argued that a 'right' to alternative accommodation for those in desperate need has developed. As observed in Grootboom and Rudolph above, the state's constitutional duty to adopt reasonable measures to ensure that people gain access to adequate housing entails providing shortterm relief for people living in crisis situations or intolerable conditions. The Court in Grootboom did not rule specifically on alternative accommodation since the government, after the community had approached the Court, offered them alternative accommodation. ${ }^{112}$ However, the Court later confirmed the undertakings made by the Western Cape provincial government and the Municipality in relation to providing temporary accommodation for the community, sanitation and basic services and water (in an interlocutory order). In PE Municipality, as noted above, the availability of suitable alternative land

106 Lingwood Michael and Another v The Unlawful Occupiers of R/E of Erf 9 Highlands, supra n. 91, at para. 18.

107 Groengras Eiendomme (Pty) Ltd v Elandsfontein Unlawful Occupants and Others, supra 99 at 141 B-E.

108 City of Cape Town and Another v The Occupiers of Erf 4832 Philippi, CPD Case No. 57 (Pty) Ltd v Elandsfontein Unlawful Occupants and Others, 46/2000, unreported at 12, per Brand.

109 Government of the Republic of South Africa and Others v Grootboom, supra n. 17 at para. 92.

110 Port Elizabeth Municipality v Various Occupiers, supra n. 48 at para. 21.

111 Budlender, 'The Right to Alternative Accommodation in Forced Evictions', in Squires et al. (eds), The Road to a Remedy: Current Issues in The Litigation of Economic, Social and Cultural Rights (Sydney: UNSW Press, 2005) 127 at 136.

112 Government of the Republic of South Africa and Others v Grootboom, supra n. 17 at para. 91. 
was an important consideration in establishing whether the state had responded reasonably to the dire situation of the occupiers in question. ${ }^{113}$

Another case that reinforces the constitutional protection of people against the loss of their homes without alternatives is Jaftha. This case was a challenge to the constitutionality of the Magistrates' Court Act that permitted the sale in execution of people's homes in order to satisfy debts. The effect of the sale in execution would be the eviction of people from their homes, without the provision of suitable alternative accommodation. The Constitutional Court held that, at the very least, any measure which permits a person to be deprived of existing access to adequate housing limits the rights protected in Section $26{ }^{114}$ Considering, inter alia, the issue of security of tenure in the light of the historical context, the Court interpreted and read words into the Magistrates' Court Act to ensure that people's homes can only be sold if a court has ordered so after considering all the relevant circumstances. ${ }^{115}$ One of the considerations would, of course, be the availability of suitable alternative accommodation. ${ }^{116}$

In the Modderklip case, the Constitutional Court held that the residents were entitled to occupy the land in question until alternative land was made available to them by the state or the provincial local authority. ${ }^{117}$ This case concerned a private landowner's efforts to execute an eviction order granted against about 40,000 people who, as a result of overcrowding and shortage of land near their informal settlement, illegally moved onto his land. The landowner was unsuccessful in getting various organs of state to assist him in enforcing an eviction order granted by the High Court. The Supreme Court of Appeal held that the state breached its constitutional obligation to both the landowner and the unlawful occupiers by failing to provide alternative accommodation to the occupiers upon eviction; and that the occupiers were entitled to occupy the land until alternative accommodation was made available to them by the state or the provincial or local authority. ${ }^{118}$ Similarly, on appeal to the Constitutional Court, it held, inter alia, that the occupiers were entitled to occupy the land until then. ${ }^{119}$

113 Port Elizabeth Municipality v Various Occupiers, supra n. 48 at para. 58.

114 Jaftha $v$ Schoeman and Others; Van Rooyen v Stoltz and Others, supra n. 50 at paras 34 and 39.

115 Ibid. at paras 52-67.

116 The Court stated further that every effort should be made to find creative alternatives that allow for debt recovery but which use execution only as a last resort; Jaftha $v$ Schoeman and Others; Van Rooyen $v$ Stoltz and Others, supra n. 50 at para. 59.

117 Modderfontein Squatters, Greater Benoni City Council v Modderklip Boedery (Pty) Ltd; President of the Republic of South Africa and Others v Modderklip Boerdery (Pty) Ltd, supra n. 46 at para. 68.

118 See generally, Modderfontein Squatters, Greater Benoni City Council v Modderklip Boedery (Pty) Ltd; President of the Republic of South Africa and Others $v$ Modderklip Boerdery (Pty) Ltd, supra n. 101 at para. 52. See also Christmas, 'Property Rights vs Socio-Economic Rights of Occupiers' (2004) 5 ESR Review 11.

119 The Court also found that, by failing to do anything to stop the occupation of the land and assist in enforcing the eviction order, the state infringed the landowner's right to an effective remedy as required by the rule of law. 
Recently, the provision of alternative accommodation for people in desperate need was one of the key issues in the case City of Johannesburg $v$ Rand Properties (Pty) Ltd and Others. ${ }^{120}$ The High Court situated the right to have access to adequate housing alongside the right to work and to a livelihood, even though the right to a livelihood is not expressly guaranteed in the South African Constitution. ${ }^{121}$ According to the Court, the right of access to adequate housing implies a right to housing at a specific location within a reasonable distance of livelihood opportunities. The High Court then dismissed the Municipality's eviction application, holding that its housing programme failed to comply with its constitutional and statutory obligations, by failing to provide suitable relief for those in desperate need of accommodation. The Court further directed the Municipality to devise and implement a comprehensive and coordinated programme to progressively realise the right to adequate housing for the desperately poor of Johannesburg. Finally, as noted earlier, the Court issued an interdict against the Municipality from seeking to evict the occupiers pending the implementation of the comprehensive housing program, or until such time as suitable adequate alternative accommodation could be provided. ${ }^{122}$

On appeal, the Supreme Court of Appeal upheld the Municipality's right in terms of the NBRA to evict residents of 'bad buildings' when it deemed it necessary for health and safety reasons, which was not dependent upon it being able to provide alternative accommodation to the occupants. ${ }^{123}$ Contrary to the High Court, the Supreme Court of Appeal was of the view that the alternative accommodation must not be at a specific location-in this case, the inner city of Johannesburg - as the Constitution does not give a person a right to housing at state expense at a locality of that person's choice. ${ }^{124}$ It would have been challenging if the Court had ordered specifically that the alternative accommodation must be in the inner city, considering, amongst other matters, the general difficulties in finding available land especially in urban areas. Notwithstanding, as pointed out by the Court, though not in the Constitution the state has a duty to give due regard to the relationship between location of residence and the place where persons can earn or try to earn their living. ${ }^{125}$ Subsequently, the Court ordered the Municipality to provide temporary accommodation to those residents who had been evicted

120 City of Johannesburg $v$ Rand Properties (Pty) Ltd and Others 2006 (6) BCLR 728 (W).

121 Ibid. at para. 64.

122 Ibid. at para. 67. For further discussion of the High Court case, see Chenwi, Advancing the Right to Adequate Housing of Desperately Poor People: City of Johannesburg v Rand Properties (Pty) Ltd and Others' (2006) 14 Human Rights Brief 13.

123 City of Johannesburg $v$ Rand Properties (Pty) Ltd and Others 2007 (6) BCLR 643 (SCA) at paras 5 and 78 .

124 Ibid. at para. 44 .

125 Ibid. 
and were in desperate need of housing assistance. ${ }^{126}$ The Court went further to state that the temporary accommodation should consist of at least the following elements: (i) a place where they might live secure against eviction; (ii) a structure that was waterproof and secure against the elements; and (iii) access to basic sanitation, water and refuse services. ${ }^{127}$ This aspect of the Court's decision affirms the constitutional commitment to establishing a society that values human dignity and requires everyone to be treated with care and concern.

As noted above, this case was further appealed to the Constitutional Court, which, after hearing the various arguments, issued an interim order directing the parties to "engage with each other meaningfully ... in an effort to resolve the differences and difficulties aired in this application' and to alleviate the plight of the applicants who live in the two buildings concerned in this application by making the buildings as safe and as conducive to health as is reasonably practicable. ${ }^{128}$

The parties have reached an agreement, which involves providing the occupiers with alternative accommodation in the inner city of Johannesburg. First, the parties agreed on a range of interim measures to improve the conditions in the two buildings in question pending relocation to the alternative accommodation. These include the provision of toilets, portable water, waste disposal services and fire extinguishers, as well as a once-off operation to clean and sanitise the properties, all at the Municipality's own expense. Second, the parties agreed that the occupiers will be provided with alternative accommodation in the inner city of Johannesburg. Similar to the Supreme Court of Appeal's ruling, the alternative accommodation will consist of at least the following elements: (i) security against eviction; (ii) access to sanitation; (iii) access to portable water; and (iv) access to electricity for heating, lighting and cooking. The occupiers are to occupy the alternative accommodation until suitable permanent housing solutions can be developed for them. The nature and location of the permanent housing options will be developed by the Municipality in consultation with the occupiers. The agreement has been endorsed by the Constitutional Court ${ }^{129}$ and accentuates the importance of the provision of suitable alternative accommodation in eviction cases, especially for those who are desperately poor, vulnerable and cannot therefore provide for themselves.

Notwithstanding, a number of issues raised in the application remain outstanding. These include but are not limited to the following: (i) the

126 Ibid.

127 Ibid. at para. 78(2.1).

128 The Rand Properties case is cited in the Constitutional Court as Occupiers of 51 Olivia Road, Berea Township, and 197 Main Street, Johannesburg v City of Johannesburg and Others, supra n. 94.

129 Case No: CCT 24/07, Order dated 5 November 2007. 
constitutionality of the relevant section of the NBRA; (ii) the practice to be adopted by the Municipality in dealing with persons occupying 'bad buildings' in the future; (iii) the applicability of PIE; (iv) the reach and applicability of Section 26 of the Constitution; and (v) the question whether, at the time the litigation was launched, the City had formulated and implemented a reasonable plan to progressively realise the rights of access to adequate housing of the occupiers and the class of persons they represent. The residual issues arising from the parties' reports will be considered in the Court's judgment. ${ }^{130}$

\section{B. Balancing Interests in Eviction Cases}

Thus, in eviction proceedings, when considering relevant circumstances as required under Section 26(3) of the Constitution, courts must consider the interest of both the unlawful occupiers and the landowner. In fact, one of the objectives of PIE is to strike a balance between a landowner's right to evict unlawful occupiers and the occupiers' right to have access to adequate housing and be protected from arbitrary eviction. Hence, where there is a clash between housing and property rights, courts have to ensure a balance between the housing rights of unlawful occupiers and the property rights of the owner of a land. The state has a duty to seek to satisfy both rights. ${ }^{131}$ The courts have developed a strategic and philosophical framework where there is a clash between housing rights and property rights. The Kyalami Ridge, PE Municipality and Modderklip cases are illustrative of the attempts by the courts to establish an appropriate relationship between property rights (Section 25 of the Constitution) ${ }^{132}$ and the right to have access to adequate housing including the protection from arbitrary evictions.

In the Kyalami Ridge case, ${ }^{133}$ the decision of the government to house a group of flood victims on land belonging to it was challenged by residents in the vicinity. ${ }^{134}$ Although the case did not deal directly with Section 25 of the Constitution, the Constitutional Court noted that the interests of both the flood victims and the environmental and property interests of the residents

130 Ibid. At the time of writing, judgment was pending.

131 Government of the Republic of South Africa and Others v Grootboom, supra n. 17 at para. 74.

132 Section 25(1), Constitution states: 'No one may be deprived of property except in terms of law of general application, and no law may permit arbitrary deprivation of property'.

133 Minister of Public Works and Others v Kyalami Ridge Environmental Association and Others 2001 (7) BCLR 652 (CC).

134 This was a case in which severe floods displaced people in Alexandra Township. As a temporary measure, the government wanted to assist the affected people by establishing a transit camp on a state-owned land, with the aim of moving the people to permanent housing once it became available. This plan was made without discussions with residents near the area of the transit camp. The residents' association challenged the government's plan on the ground that it was not supported by legislation, and that it contravened a town planning scheme, and land and environmental legislation. 
have to be taken into account in the decision-making process. ${ }^{135}$ The Court stated that the fact that property values in the vicinity may be affected by low-cost housing cannot in the circumstances of the case stand in the way of the constitutional obligation that government has to address the needs of homeless people, and its decision to use its own property for that purpose. ${ }^{136}$ The Court then held that the decision by government to establish a temporary camp was lawful as it was intended to give effect to its constitutional obligation to provide access to adequate housing.

In the PE Municipality case, the Constitutional Court noted that the use of the term 'just and equitable' in the eviction legislation (PIE) relates to both the interests of landowners and of unlawful occupiers. While acknowledging the complexities involved in balancing these interests - the constitutional rights of landowners and unlawful occupiers - the Court pointed out three salient features of the way the Constitution approaches the interrelationship between land, homelessness, hunger and respect for property rights: First, the rights of the dispossessed in relation to land are not generally in unqualified terms as rights intended to be immediately self-enforcing, presuppose, in the main, the adoption of legislative and other measures to strengthen the rights. ${ }^{137}$ Secondly, people living in informal settlements may be evicted, even if it results in loss of a home. ${ }^{138}$ Thirdly, there is the need to seek concrete and case-specific solutions to the difficult problems that arise. ${ }^{139}$ Hence, where there is a clash between property rights and the genuine despair of people in dire need of accommodation, the judicial function is not to establish a hierarchical arrangement between the different interests involved. Put differently, the judicial function is not to automatically privilege in an abstract and mechanical way property rights over the housing rights of those affected. ${ }^{140}$ In such instances, as stated by the Constitutional Court, the function of the court is "to balance out and reconcile the opposed claims in as just a manner as possible taking account of all the interests involved and the specific factors relevant in each case. ${ }^{141}$ Therefore, the state must show equal accountability to occupiers and landowners. If, for instance, the state fails to provide alternative land in an eviction case in which it should have done so, it breaches its constitutional duty to both the landowner and unlawful occupiers. Accordingly, the Court in PE Municipality found that it was not just and equitable to evict the occupiers. ${ }^{142}$

135 Minister of Public Works and Others v Kyalami Ridge Environmental Association and Others, supra n. 133 at paras 103, 105 and 106.

136 Ibid. at para. 107.

137 Port Elizabeth Municipality v Various Occupiers, supra n. 48 at paras 20.

138 Ibid. at para. 21.

139 Ibid. at para. 22.

140 Ibid. at para. 23.

141 President of the Republic of South Africa and Another v Modderklip Boedery (Pty) Ltd and Others, supra n. 46 at para. 22 .

142 Ibid. at para. 58. 
The Modderklip case posed a clear conflict between the duty of the state to protect the landowner's property rights and its duty to provide access to adequate housing. The Supreme Court of Appeal held in this case that, by failing to provide alternative accommodation to the occupiers upon eviction, the state breached its constitutional obligation to both the landowner and the unlawful occupiers. ${ }^{143}$ On appeal to the Constitutional Court, the state's main contentions were the following: First, it challenged the finding by the Supreme Court of Appeal that the landowner's right to property and the occupiers' rights to have access to adequate housing had been breached. Second, the state argued that the landowner was not entitled to the relief it claimed because it had neglected to apply for an urgent eviction order in good time. ${ }^{144}$ The Court did not engage with arguments regarding violations of the landowner's right to property. Rather, it focussed on the second contention. The Court was of the opinion that it is unreasonable to force the landowner to bear the burden that is on the state of providing the occupiers with accommodation. ${ }^{145}$ However, the Court found that, by failing to do anything to stop the occupation of the land and assist in enforcing the eviction order, the state infringed the landowner's right to an effective remedy as required by the rule of law and entrenched in Section 34 of the Constitution. ${ }^{146}$ Although the Court did not deal with the landowner's property rights, its judgment confirms that, in eviction cases, the rights of landowners - be it the right to property or other rights - have to be balanced with the right to have access to adequate housing of unlawful occupiers.

\section{Conclusion}

Courts do have an important role in enforcing the right to adequate housing, especially in the context of an eviction. Judicial oversight is crucial in ensuring that constitutional rights are adequately enforced, that evictions are justifiable, and that all the relevant circumstances are taken into account before resort is had to such a drastic measure that causes social disruption and has negative impacts on a range of human rights. The legislative provisions on the rights to adequate housing and to protection from forced evictions form the skeleton, which the courts add flesh to by expanding on the provisions, resulting in safe, secure and affordable living conditions for the poor and vulnerable. The South African constitutional jurisprudence also advances what the right to

143 Modderfontein Squatters, Greater Benoni City Council v Modderklip Boedery (Pty) Ltd; President of the Republic of South Africa and Others v Modderklip Boerdery (Pty) Ltd, supra n. 101 at para. 52.

144 Ibid. at para. 22.

145 Ibid. at para. 45.

146 Ibid. at para. 51. 
have access to adequate housing entails. Housing means a lot more than a roof over one's head. For a person to have access to adequate housing, there must be land, the house itself, services such as the provision of water and the removal of sewage and the financing of these. In addition, it is not only the state that is responsible for providing housing. Other people and structures within our society must be permitted by legislative and other measures to provide housing. This is because the state's duty is to create the conditions for access to adequate housing for people at all economic levels of a society.

South African courts have made significant progress in ensuring greater protection for those faced with eviction, while, at the same time, recognising the rights of landowners. A positive aspect of the jurisprudence of the courts is its use of international law in non-binding international instruments. The constitutional jurisprudence is in fact consistent with the international framework as it underscores most of the international standards on evictions. The courts' approach is similar to that of the CESCR, requiring a high standard of justification for forced evictions. It is evident from the jurisprudence that the state has a duty to ensure that an eviction is carried out humanely. If the eviction results in possessions and building materials being destroyed and burnt, it could constitute a violation of the state's duty to provide access to adequate housing.

Notwithstanding, the eviction problem in South Africa is still an issue that one should be particularly concerned about. Due to poor implementation of certain laws and policies as well as of court judgments, the sad reality is that many people are still faced with the threat of evictions. In this regard, at the end of his mission to South Africa in April 2007, the UN Special Rapporteur on adequate housing criticised the practice of forced evictions in the country as it renders people homeless; and called for a moratorium on evictions until all national, provincial and local legislation, policies and administrative actions are brought into line with constitutional provisions and relevant constitutional court judgments that protect the right to adequate housing and freedom from evictions. ${ }^{147}$

The South African experience shows that having a myriad of progressive laws and policies on housing rights and evictions is not sufficient, as their actual enforcement is the most vital facet. Though courts do have an important role in ensuring adequate enforcement of the rights to adequate housing and to protection from forced evictions, the impact is limited if their decisions are not enforced adequately. 